\title{
Analysis of post-mining excavations as places for municipal waste
}

\author{
Justyna Górniak-Zimroz ${ }^{1, *}$ \\ ${ }^{1}$ Wroclaw University of Science and Technology, Faculty of Geoengineering, Mining and Geology, \\ 27 Wyb. Wyspianskiego St., 50-370 Wroclaw, Poland
}

\begin{abstract}
Waste management planning is an interdisciplinary task covering a wide range of issues including costs, legal requirements, spatial planning, environmental protection, geography, demographics, and techniques used in collecting, transporting, processing and disposing of waste. Designing and analyzing this issue is difficult and requires the use of advanced analysis methods and tools available in GIS geographic information systems containing readily available graphical and descriptive databases, data analysis tools providing expert decision support while selecting the best-designed alternative, and simulation models that allow the user to simulate many variants of waste management together with graphical visualization of the results of performed analyzes. As part of the research study, there have been works undertaken concerning the use of multi-criteria data analysis in waste management in areas located in southwestern Poland. These works have proposed the inclusion in waste management of post-mining excavations as places for the final or temporary collection of waste assessed in terms of their suitability with the tools available in GIS systems.
\end{abstract}

\section{Introduction}

Despite the desire to reduce the amount of waste produced and to intensify the disposal processes in waste management, landfill sites are necessary for placing waste that cannot undergo waste treatment in the present state of the art. The need to build new landfills results from the fact that existing ones are being closed due to overfilling or failure to meet stringent legal, sanitary or environmental requirements $[1,2]$. Therefore, research was carried out to identify new sites for the location of waste management facilities. Designing these sites is a complex issue in which many factors have to be taken into account in determining the best location for a landfill. Therefore, multi-criteria data analysis can be used to determine this location. This analysis aims at selecting the optimal solution according to different criteria that are difficult to compare with each other and affect the implementation and operation of the solution. It is used as a decision support tool when multiple criteria are available. The selected examples described in [3-8] constitute the applications of multi-criteria data analysis in the studies concerning the support in the

Corresponding author: justyna.gorniak-zimroz@pwr.edu.p1 
processes of making planning decisions. It was proposed to calculate the suitability of land in waste management by means of multi-criteria data analysis based on the equation:

$$
S=\sum_{i=1}^{n} w_{i} \cdot p_{i}
$$

where:

$S$ - land suitability

$w_{i}$ - the weight of the criterion

$p_{i}$ - value of the parameter

$i$ - criterion

$n$ - number of criteria

$$
\begin{aligned}
& \sum_{i=1}^{n} w_{i}=1 \\
& i \in<1, n>i
\end{aligned}
$$

The research offered the inclusion of post-mining excavations in waste management, which can be used to prolong mining activities and at the same time contribute to the development of mining services in the waste market. However, the location of the waste management facility in each excavation is not possible due to numerous spatial, social and environmental constraints [9]. Therefore, it is necessary to assess the suitability of postmining excavations in multi-criteria waste management using data analysis methods.

\section{Materials and methods}

The analyses were carried out for municipal waste management as well as hazardous and radioactive waste, for which an appropriate area of investigations with precise limits was chosen. These boundaries include spatially linked settlements that are the source of waste generation and mining areas, together with the common solutions for waste management and waste management, and the rational development of mining areas in this territory. The decision concerning the location of the facility related to the management of hazardous and radioactive waste is made by the Minister competent for the economy, the Minister responsible for the environment and the Department of Waste Disposal. Such an object should be a regional object. Therefore, the region of Lower Silesia has an area of 19936 $\mathrm{km}^{2}$ with localized deposits of hard coal, copper ore, barite, white-burned clay, rock salt and gypsum and anhydrite (Figure 1a). Despite the fact that municipal waste management is a responsibility of the municipality itself, according to a rational waste management, newly created municipal waste management facilities should perform over-the-counter functions. Therefore, the pilot areas are limited to the administrative boundaries of the Milicz, Wrocław and Swidnickie districts (Figure 1b). The limitations of the study area do not affect the analysis method itself and do not limit the applicability of the developed algorithms and analysis tools. Extending the research area requires the introduction of new empirical data into the system. 


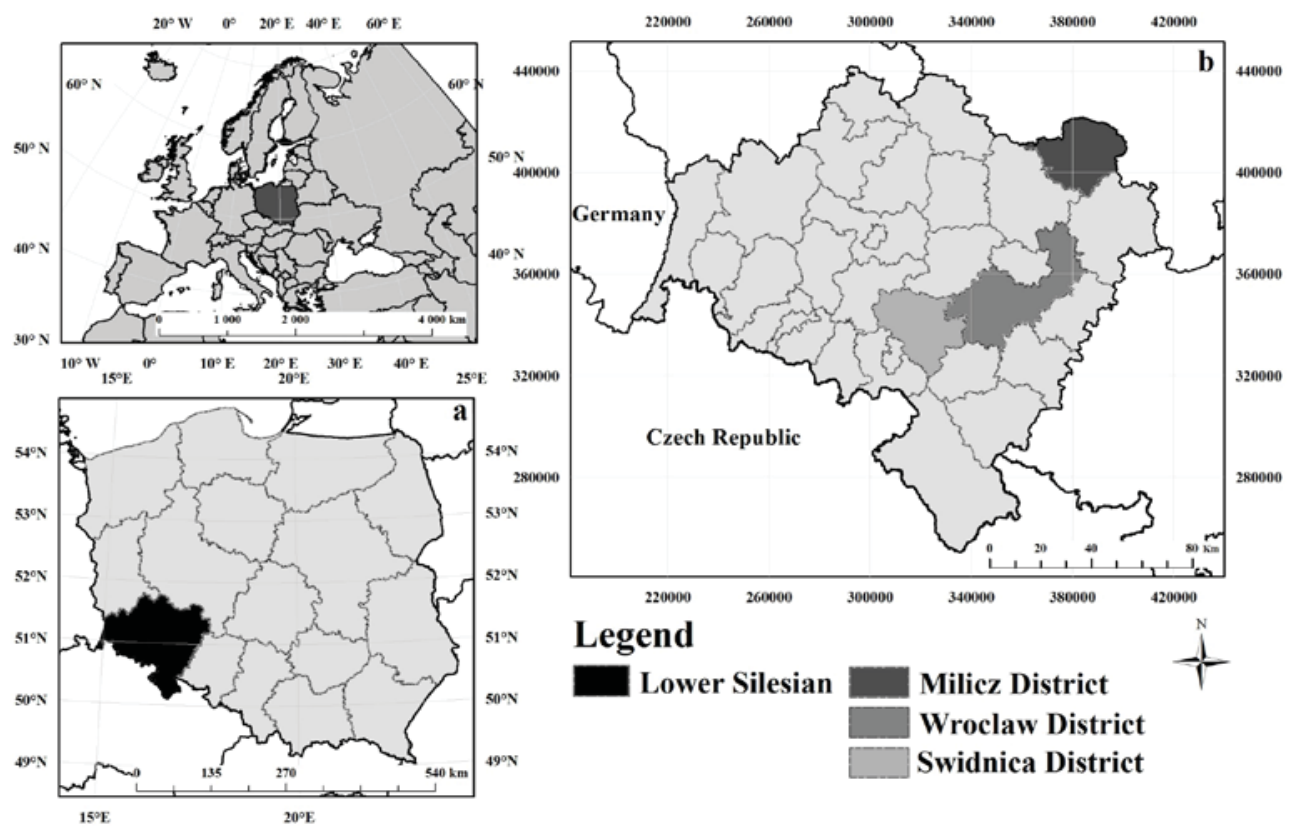

Fig. 1. Localization of selected areas for analyses against the background of Poland (a) and of Lower Silesia (b).

The suitability of the post-mining excavation is described in [10-12] as a function of many variables of unknown form divided into four main groups of factors, i.e. spatial factors $(v)$, environmental factors $(p)$, technical factors $(t)$ and social factors $(s)$ :

$$
\begin{gathered}
j w=f\left(x_{1}, x_{2}, \ldots, x_{n}\right) \\
j w=f(v, p, t, s)
\end{gathered}
$$

where:

$x$ - the factor describing the quality of the excavation

$v$ - spatial factors

$p$ - environmental factors

$t$ - technical factors

$s$ - social factors

The function describing the state of the excavation, the so-called "quality of the excavation" depends on different variables in different ways, leading to the following dependence:

$$
j w=\sum_{i}^{n} w_{i} \cdot x_{i}
$$

where:

$w_{i}$ - weight determining the value of the i-th factor describing the quality of the excavation $x_{i}$ - the i-th factor describing the quality of the excavation

Designing weights is a complex issue, but it is possible through empirical research. Determination of the value of the "excavation quality" function is necessary to verify in which of the ranges of variability of this function, where ranges correspond with the suitability classes of the excavation, the evaluated excavation site is found. In the presented research, the factors and their weights were selected on the basis of the literature on the 
subject, legal references and surveys of experts dealing with spatial planning, waste management, environmental protection and mining. The number of factors describing the suitability of the post-mining excavation in the conducted research was selected for the analyzed case. Data and knowledge of the content needed for analyzes were collected in databases developed for mining objects and for selected research areas.

Research in the described cases was made by means of selected spatial analyzes available in GIS systems. Their final result was to obtain a map of the assessment of the suitability of excavations for locating a waste management facility. Figure 2 shows schematically how the research was conducted.

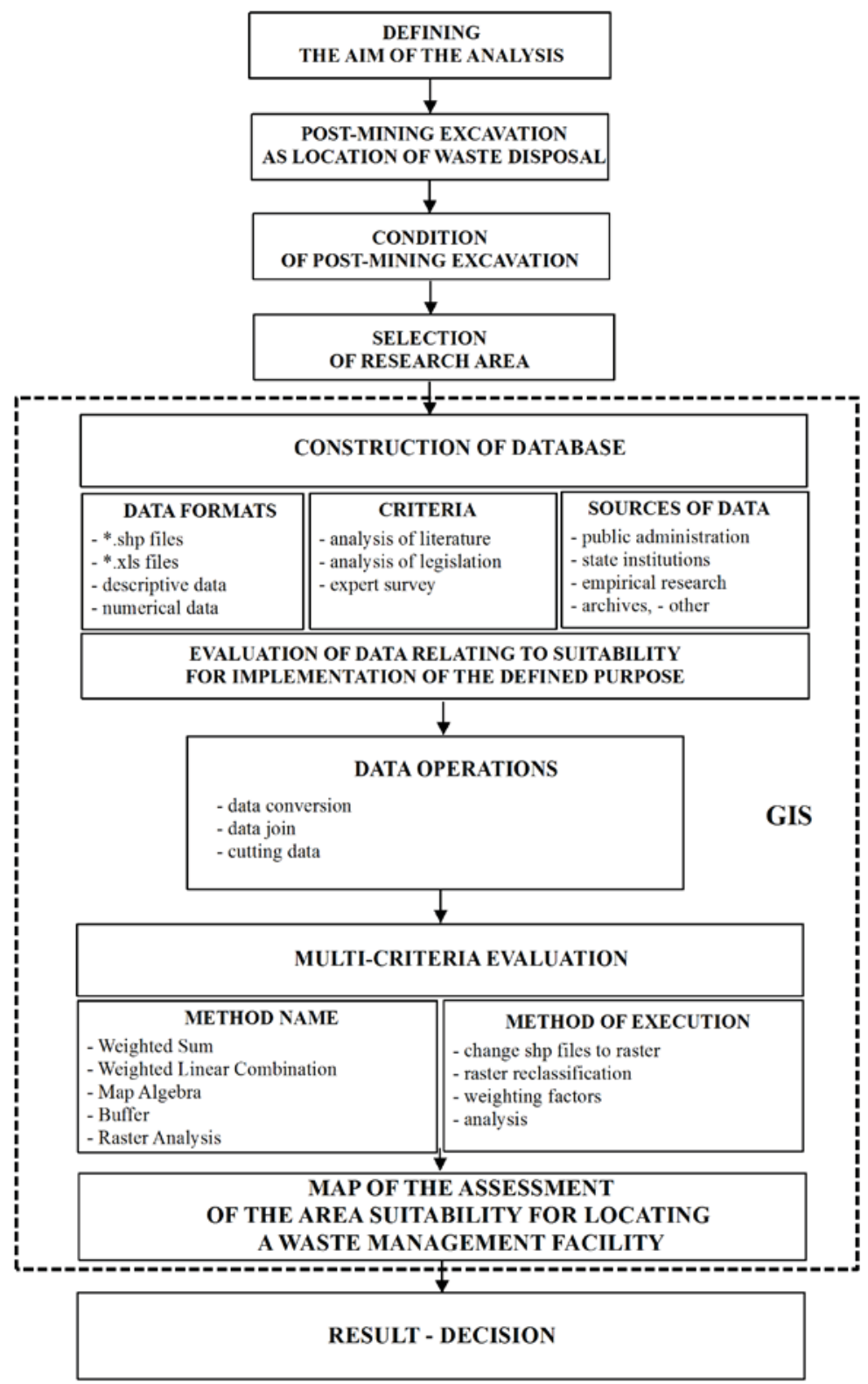

Fig. 2. Methodology for the evaluation of the suitability of post-mining areas in waste management. 


\section{Results}

\subsection{Milicz District}

A database of 98 factors was developed for the Milicz District based on the analysis of the literature on determining the factors defining the direction of reclamation, the factors determining the use of post-mining areas for the disposal of municipal waste, the factors taken into consideration during the selection of the site for the location of the municipal landfill and the analysis of the Polish and EU law on environmental protection and the management of municipal waste. These factors are described by quantitative and qualitative variables that were converted into numerical variables. The numerical value for the i-th variable describing the quality of the post-mining excavation was determined according to the following principle: the advantageous factor for the location of the site was 1, neutral or no factor was 0 , and the disadvantageous factor for the location of the site was -1 [10-13].

Figure 3 shows the result of the analysis of the suitability of the site for the location of the municipal waste disposal landfill made for 16 rock raw material deposits from the Milicz District. This analysis takes into account the influence of other structures located within the analysed land on the location of the landfill, i.e.: the proximity of post-mining areas in relation to waste generating sources and roads, and the remoteness of groundwater intakes, rivers, reservoirs and nature reserves. The suitability of the area is depicted in colour, the brighter the colour, the better place for the location of the landfill. The analysis was done in ArcGIS using multi-criteria data analysis by the Weighted Sum Method. The obtained result was compared with the deposits located in the Milicz District and it was found which is located in the highest rated area with regard to its waste management suitability. On the obtained map of results, this area was marked with the location of the clay raw material deposits of Zduny-Cieszków building ceramics [10-13].
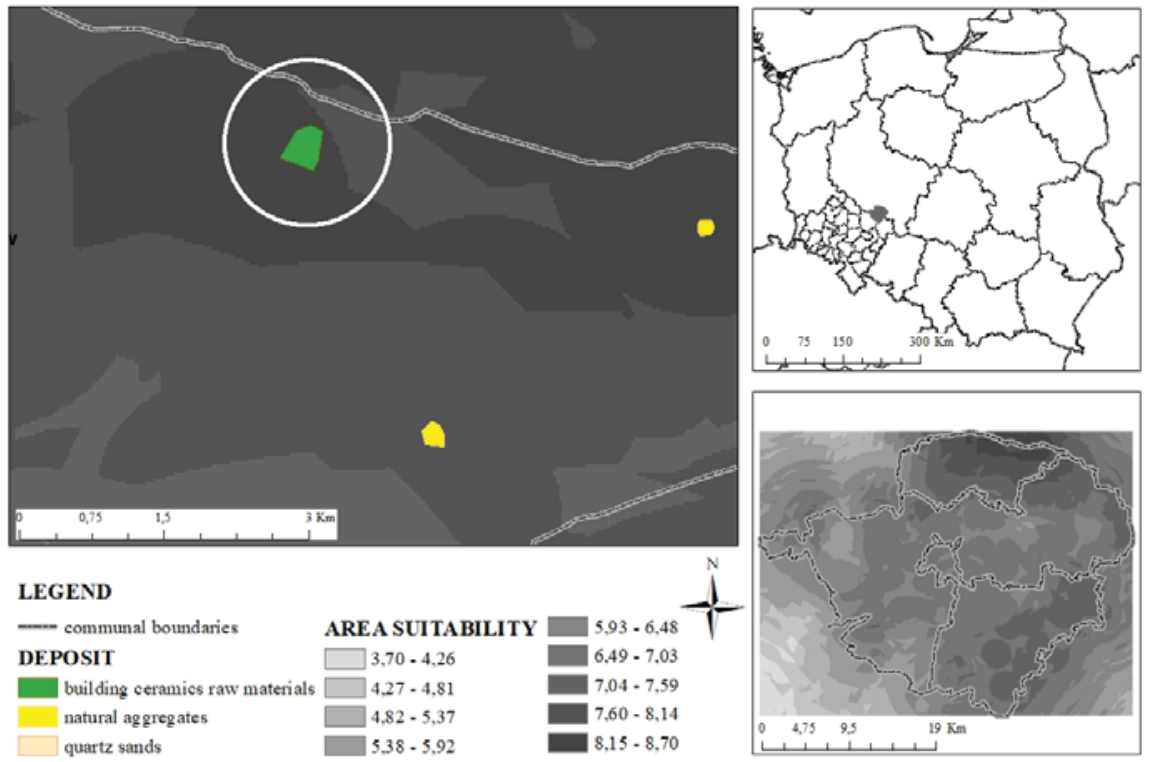

Fig. 3. Analysis of the suitability of the site for the location of a municipal landfill in the Milicz District. 
For the Wroclaw District, 59 rock raw material deposits were analyzed in terms of their suitability in the management of municipal waste. A buffer construction tool was constructed for five criteria based on the literature for the following parameters: $500 \mathrm{~m}$ for municipal waste generation sources, $300 \mathrm{~m}$ for the communication network, $90 \mathrm{~m}$ for the hydrographic network, $500 \mathrm{~m}$ for inland surface water bodies, and $300 \mathrm{~m}$ for landscape parks with buffer zones. On the obtained restrictions there was a layer applied with the location of deposits and analysis of their suitability [14].

Figure 4 shows the results. In the Wroclaw District only 4 deposits are located outside of the restrictions in question. These are the deposits of natural aggregates Jezierzyce Wielkie and Jezierzyce Wielkie I as well as deposits of road and building stones Jordan and Jordan 1 marked in the picture.
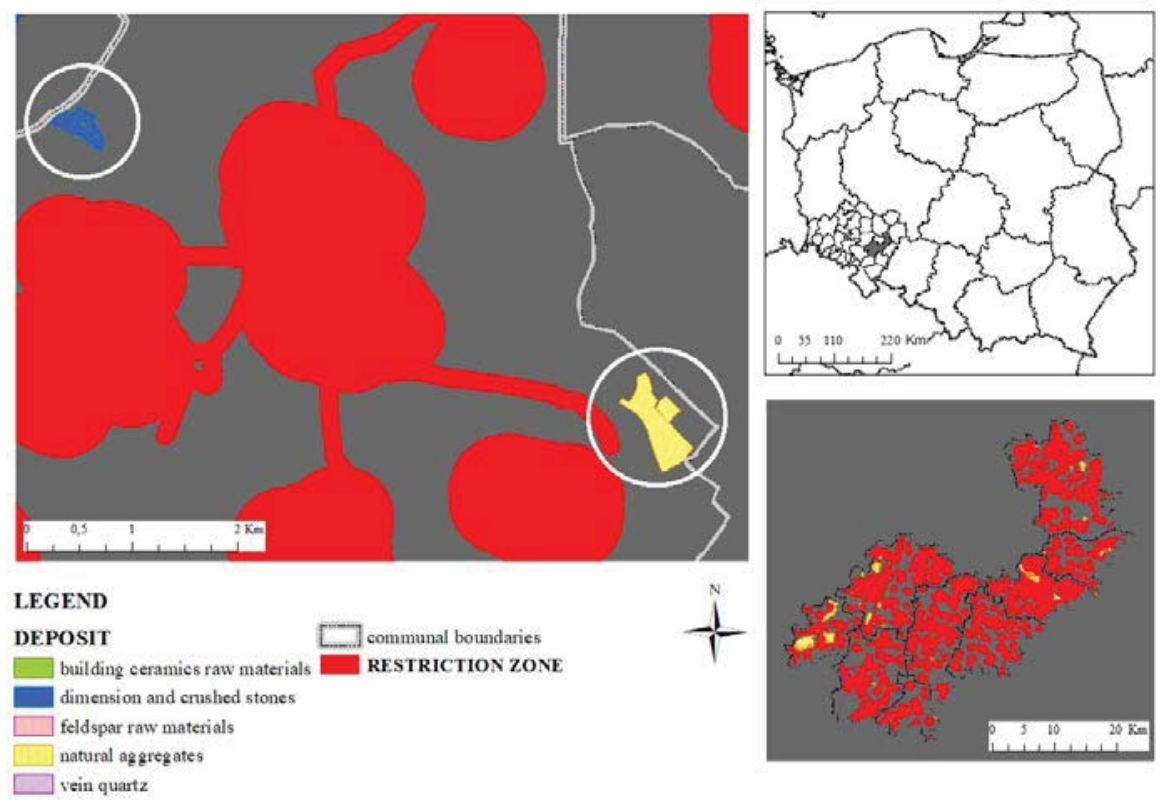

Fig. 4. Analysis of the suitability of the site for the location of a municipal landfill in the Wroclaw District.

\section{3 Świdnica District}

In the Świdnica District, 94 rock raw material deposits were analyzed. The factors defining the suitability of the post-mining area in waste management were determined on the basis of the analysis of literature and legal references. 48 factors were divided into six groups: development, communication network, water and wetlands, forests, protected areas, soils, grasslands and landslides. Weights for factors were identified during the survey of mining, waste management and environmental experts [15]. After preparation of the database, multi-criteria data analysis was performed by means of buffering and map algebra consisting in performing algebraic operations on rasters [16]. A layer of deposits was applied on the resulting raster to analyze which of them could qualify as a location for a municipal waste disposal site. In the Świdnica District, 40 rock raw material deposits were identified. The resultant map is shown in Figure 5. The dark-green colour means the areas with the best suitability for the location on the map. The map shows the deposits located in these areas. These are the Gniewków I granite deposit, the Grodziszcze gneiss deposit, the Julia kaolin deposit and the Wiry-Gogołów magnesite deposit [15]. 

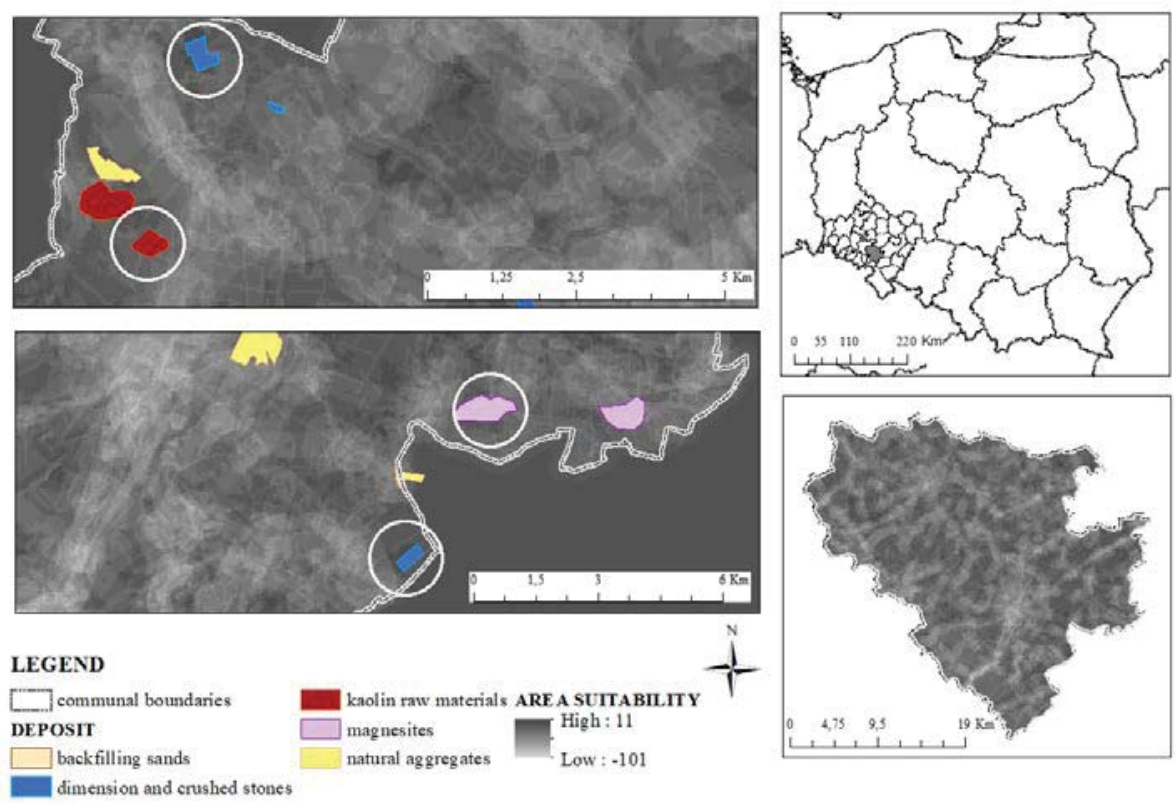

Fig. 5. Analysis of the suitability of the site for the location of a municipal landfill in the Swidnica District.

\subsection{Lower Silesia}

In the Lower Silesia area, underground excavations of hard coal deposits, copper ores, gypsum and anhydrite, barite, white-burned clays and rock salt deposits were selected. These deposits were analyzed for the location of hazardous and radioactive waste disposal sites. The selection of factors was made on the basis of literature and legislation regulating issues related to the management of hazardous and radioactive waste. The geobase with factors was divided into five groups: factors that define areas of nature protection, factors describing soils, factors concerning hydrographic structures, factors related to afforestation, as well as building and infrastructure factors. As a method of multi-criteria spatial analysis, a method of Weighted Linear Combination was chosen. WLC consists in a simple combination of layers based initially on multiplication of parameters and estimated weight of a given criterion and then on the addition of multiplication results of all criteria [18]. Weights for factors were based on the analysis of literature and legislation related to the studied subject matter. For weighting, the scale from 0 to 10 was assumed, where 10 is the best location for the factor and 0 is the exclusion of the location [17].

Figure 6 shows the result of the assessment of the suitability of the site for the location of the hazardous and radioactive waste landfill. The barriers strictly limiting the suitability of the site and the deposit were applied on the resultant map and it was analyzed which of these deposits could be used as a location for the site. As a result of the analyzes, it was obtained that there are Nowy Ląd deposits of gypsum and andyrethrite, Jeżów Sudecki barite deposit and deposits of Sieroszowice and Bądzów salts, which are the accompanying minerals for copper ores. 

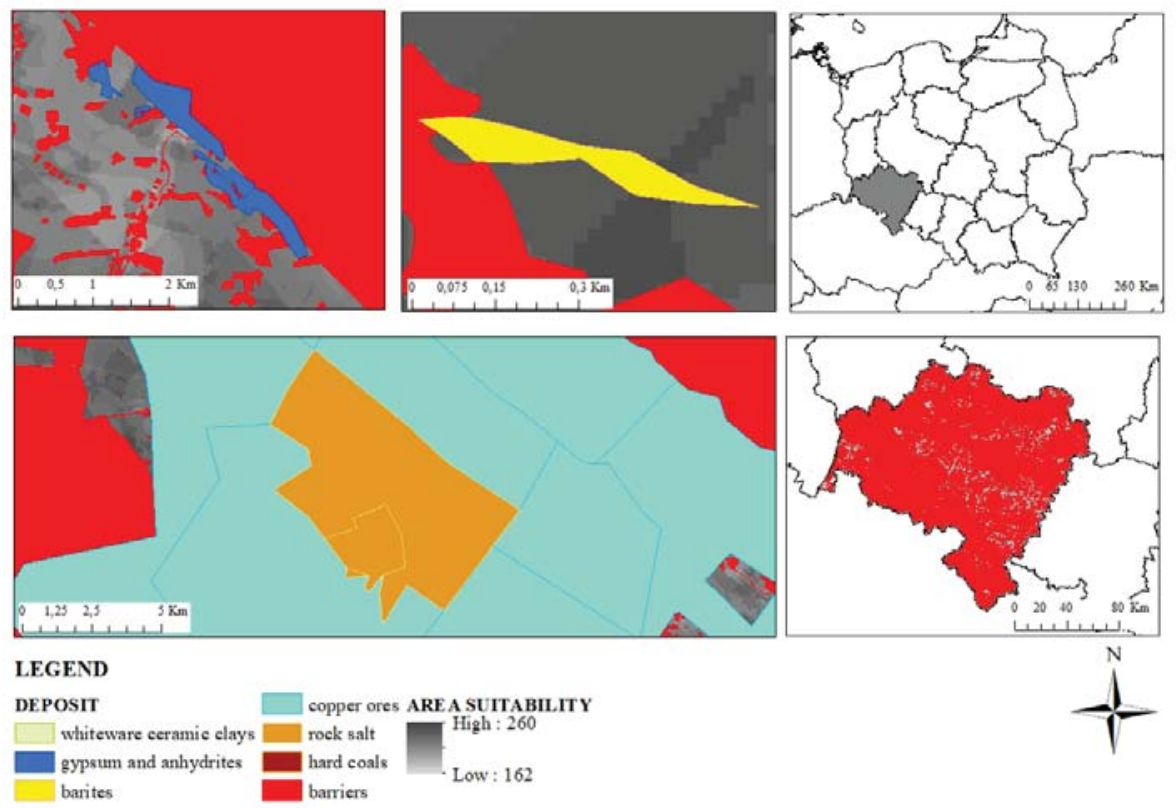

Fig. 6. Analysis of the suitability of the site for the location of the hazardous and radioactive waste disposal landfill in Lower Silesia.

\section{Conclusion}

The research showed that multi-criteria data analysis used to assess the suitability of a site for the location of a waste management facility can be applied as a useful tool in spatial management to support decision-making processes in waste management. Choosing a location involves analyzing many factors that influence one another. The suitability maps generated by multi-criteria spatial analysis show the information on the site and the requirements that should be met by the location of the municipal waste disposal facility and the hazardous and radioactive waste site. It is important that the use of GIS tools in the decision-making process also makes it possible to incorporate in the analysis the legal aspect understood as the content of legislation, regulations and directives translated into spatial data used in the analysis. However, as with most automated processes, it is necessary to verify the results with a reality that do not explicitly exclude areas covered by factors that exclude the location of the research objective, namely, determining the location of the site, but only reduce their availability. Therefore, multi-criteria data analysis in GIS environment can be considered as a decision support tool. Further studies can use the results obtained during the analysis and provide a detailed analysis of the geological and hydrogeological structure of the areas designated as the most favourable for the location of the landfill.

This article was financed with the research project no. 0401/0174/16 Data mining in modelling environmental changes and Grant no. 0401/0128/17.

\section{References}

1. Basic statistics of the European Community, EU, Eurostat, Brussels, http://ec.europa.eu/eurostat/en, March (2017) 
2. American Environmental Protection Agency, https://www.epa.gov/landfills, March (2017)

3. J. Blachowski, Environ Earth Sci., Springer 71 (2014)

4. J. Chen, Environmental Systems Research 3/13 (2014)

5. J.R. Eastman, M.E. Van Fossen, L.A. Solorzano, Transition potential modelling for Land-Cover change, in GIS, Spatial Analysis and Modelling, editors: Maguire D.J., Batty M. and Goodchild F., ESRI Press, 380 New York Street, Redlands California (2005)

6. J. Górniak-Zimroz, Applied Mechanics and Materials 683 (2014)

7. G.A. Kiker, T.S. Bridges, A. Varghese, T.P. Seager, I. Linkovjj, Integrated Environmental Assessment and Management 1 (2) (2005)

8. J. Malczewski, International Journal of Geographical Information Science 20 (7), August (2006)

9. B. Radwanek-Bąk, R. Patorski, Possibilities of using post-mining excavations on landfills, work edited M. Kistowskiego Landscape-ecological studies for sustainable development programming review of polish experiences on the eve of European Union accession, The Problems of Landscape Ecology XIII, Gdańsk (2004)

10. J. Górniak-Zimroz, Integrated municipal waste management and post-mining excavation, doctoral thesis, unpublished work in Polish (2004)

11. J. Górniak-Zimroz, J. Malewski, Application of the Kohonen neural network for classification of mining voids, AI-METH 2004, Symposium on Methods of Artificial Intelligence, Gliwice (2004)

12. J. Górniak-Zimroz, J. Malewski, Decision support system for management of municipal waste and mining voids, MPES 2004, the Thirteenth International Symposium on Mine Planning and Equipment Selection, Wrocław (2004)

13. J. Górniak-Zimroz, J. Malewski, J. Woźniak, The methodology of development of decision support system for management of municipal waste and mining voids, Sustainable post-industrial land management, SPILM 2004, The international conference, Kraków (2004)

14. J. Górniak-Zimroz, J. Malewski, Logistics aspects of municipal waste management, Management of municipal waste in the Wroclaw District in the light of solutions implemented in the Upper Rhine Department (France) and the Borken District (Germany), International Conference, Wroclaw (2005)

15. S. Sewina, Analysis of post-mining excavations as potential landfills of municipal waste - analysis for the selected district, master thesis carried out under the supervision J. Górniak-Zimroz at the Faculty of Geoingeneering, Mining and Geology Wroclaw University of Science and Technology, unpublished work in Polish, (2016)

16. C.D. Tomlin, Elsevier, Landscape and Urban Planning 30 (1994)

17. A. Dymacz, Determination of potential locations of underground hazardous and radioactive waste dumps in Lower Silesian Voivodeship, engineering work carried out under the supervision J. Górniak-Zmroz at the Faculty of Geoingeneering, Mining and Geology Wroclaw University of Science and Technology, unpublished work in Polish (2017)

18. J. Eastman, Guide to GIS and Image Processing, 2, IDRISI 32 (2001) 